\title{
Research on Service Quality Evaluation of Rural Tourism
}

\author{
Yu Huang \\ Xi'an International University, Xi'an, 710077, China
}

Keywords: Rural tourism, Service quality, assessment application

\begin{abstract}
With the continuous development of rural tourism, the quality problem of service is gradually emerging. Service quality is a subjective evaluation of tourists at the end of their service. It affects the tourists' willingness to make recommendations and revisit. Through combing and defining the relevant concepts of rural tourism service quality, this paper constructs the rural tourism service quality model, and takes Wanhua village as the object to evaluate and analyze its rural tourism service quality. There is no doubt about the importance of rural tourism service quality to the development of rural tourism. Government departments and rural tourism operators are seriously seeking ways to improve service quality. The government can guide and regulate the development of rural tourism by formulating relevant policies. The operators should conscientiously study and improve their own quality to meet the needs of the future development of rural tourism. Through the construction of rural tourism service quality model, this paper evaluates it and puts forward some suggestions for improvement.
\end{abstract}

\section{Relevant Concept Definitions of Service Quality of Rural Tourism}

Definition of Rural Tourism. Rosa, Pablo\&Libia (2007) summary of the research of other scholars, that rural tourism includes three characteristics: 1. tourism activities happened in rural areas; 2. rural tourism tourists choose rural tourism is the main motivation to experience rural life and feel the natural scenery; 3 . visitors to stay for a short time, usually in the weekend travel.

Definition of Service Quality. Service is an intangible product, generated in the interaction between service personnel and customers, and strives to satisfy customers. Service generally has 4 characteristics of invisibility, simultaneity, volatility and heterogeneity (Bitran\&Lojo, 1993, Parasuraman, etc., 1993).

Tourism Service Quality. Most of the scholars from the vertical angle of tourism service quality is divided into technical quality and functional quality, technical quality is provided to the tourist value, is the result of a service, including the service facilities, service environment; quality function refers to the service, including the service attitude, service, service behavior and other instruments.

\section{Evaluation Model of Service Quality of Rural Tourism}

In 1960s, the western scholars put forward the theory of customer expectation model, which provided a theoretical basis for service marketing decision and consumer purchase service decision. The expected value model theory refers to the service industry in addition to multiple attributes has obvious attribute, attribute importance and decisive attributes, organization and service the same because of the difference of service environment and service object and attribute position will change. Rural tourism consumer choice of services is based on the expected value model theory, a comprehensive study of the properties of the services and the best choice to establish rural tourism service quality evaluation model, you can use the expected value model method to evaluate the rural tourism service quality, which can be expressed in a formula: 


$$
A_{j k}=\sum_{i=1}^{n} W_{i k} B_{i j k}
$$

The evaluation model of rural tourism service quality can be used to calculate the comprehensive service quality of rural tourism consumers. In the formula, $A_{j k}$ is consumer $k$ 's attitude towards brand $\mathrm{j}$; $\mathrm{W}_{\mathrm{ik}}$ is the weight given by consumer $\mathrm{k}$ to I brand attributes; $\mathrm{B}_{\mathrm{ijk}}$ is the strength of belief strength of $\mathrm{i}$ attribute provided by consumer $\mathrm{k}$ to $\mathrm{j}$ brand; $\mathrm{n}$ is attribute number.

\section{Evaluation System Design of Service Quality Model of Rural Tourism}

Index Selection of Service Quality Model of Rural Tourism. Whether the result of rural tourism service quality meets the needs of customers needs to be evaluated by customers. The customer evaluation of service quality is the evaluation from the point of view of the market and the cognition of the customer. It is the basic evaluation and basic measurement of the service quality. Therefore, to identify the evaluation index of rural tourism service quality, it means that the guiding direction of service behavior is clear, and it also provides the basis for the service quality management of rural tourism. According to the characteristics of rural tourism service quality, combined with the service content for customers, the evaluation index of rural tourism service quality mainly includes the following six aspects:

First, hardware quality: guest rooms, washing rooms, TV programs, and interior decoration.

Second, dishes quality: dishes, drinks color, aroma, shape and flavor, as well as varieties, structures, quality standards, unity, etc..

Third, food prices: the price of dishes is reasonable, and the price and rural tourism grade match, etc..

Fourth, safety and health: food, drinks, dining environment hygiene, safety standards, and the dining environment is safe.

Fifth, service level: service personnel's appearance, courtesy, courtesy, service attitude, health, service skills, service efficiency and so on.

Sixth, featured services: specialty food products and related products and services, as well as personalized service and service innovation.

Evaluation Process of Service Quality Model of Rural Tourism. The quality of rural tourism service quality is generally measured and quantified, and the specific process is as follows:

The first step is to measure the customer's expected quality of service;

The second step is to measure customer perceived service quality;

The third step is to determine the quality of service, that is, service quality = expected quality of service, perceived service quality.

The steps to quantify the quality of service are as follows:

The first step is to select the evaluation criteria of service quality;

The second step is to determine the weights according to the standards of the surveyed service industry;

The third step is to design 3 5 specific questions for each standard;

The fourth step is to make a questionnaire;

The fifth step is to issue questionnaires and ask customers to mark them one by one;

The sixth step is to make a comprehensive statistics of the questionnaire;

The seventh step is to calculate the expected quality and perceived quality;

The eighth step, according to the expected value model, obtained the gap value, the greater the value, showed that perceived quality from the expected quality gap is large, the greater the service quality, show that perceived quality from the expected quality gap is bigger, the worst quality of service; on the contrary, it is a good quality of service. 


\section{Application and Analysis of Evaluation of Service Quality of Rural Tourism}

Research Design. In Yanan City, Shaanxi Province we selected million rural tourism consumer customers, in the form of random sampling investigation and access to relevant data.

This study used questionnaires to collect data, questionnaire design is based on SERVQUAL evaluation model, constructed on the basis of our rural tourism service quality evaluation of the 6 indexes and 26 level two indexes. Using the method of random sampling in the rural tourism to the rural tourism blossoms, 500 questionnaires, 438 were recovered, the recovery rate was $87.6 \%$.

First of all, select the service quality evaluation index. According to the above, according to the hardware, equipment, atmosphere, dishes quality, food and beverage prices, safety and health, service level, characteristic service these six aspects as the rural tourism service quality evaluation index.

Secondly, aiming at these six aspects, to determine the weight of flower of rural tourism service quality evaluation index.

Table 1 Index of service quality of rural tourism and it's weight

\begin{tabular}{ll}
\hline Service quality evaluation index & Weight \\
\hline Hardware, equipment, atmosphere & 0.1 \\
Dishes quality & 0.3 \\
Catering price & 0.1 \\
Safety hygiene & 0.2 \\
service level & 0.2 \\
Characteristic service & 0.1 \\
Total & 1.0 \\
\hline
\end{tabular}

Table 2 Hardware equipment and atmosphere analysis

\begin{tabular}{lcc}
\hline \multicolumn{1}{c}{ Hardware equipment and atmosphere analysis, } & $\begin{array}{c}\text { Expected } \\
\text { quality }\end{array}$ & $\begin{array}{c}\text { service } \\
\text { quality }\end{array}$ \\
\hline $\begin{array}{l}\text { 1. Does the store have modern equipment? } \\
\text { 2. Are food and beverage facilities and facilities attractive? }\end{array}$ & 80 & 75 \\
$\begin{array}{l}\text { 3. Does the hardware in the store match the service provided by } \\
\text { the waiter? }\end{array}$ & 85 & 70 \\
$\begin{array}{l}\text { 4. Is the restaurant dining environment standard unified, warm } \\
\text { and comfortable? }\end{array}$ & 80 & 70 \\
\hline 5. Is the store image unified? & 85 & 70 \\
\hline Average value & 82.4 & 73 \\
\hline
\end{tabular}


Table 3 Analysis results of food quality

\begin{tabular}{lcc}
\hline \multicolumn{1}{c}{ Food quality analysis } & $\begin{array}{c}\text { Expected } \\
\text { quality }\end{array}$ & $\begin{array}{c}\text { service } \\
\text { quality }\end{array}$ \\
\hline $\begin{array}{l}\text { 1.According to grades, the reception of consumer demand for } \\
\text { food varieties? }\end{array}$ & 90 & 80 \\
$\begin{array}{l}\text { 2. Whether the varieties and kitchen cooking technology, } \\
\text { production capacity to adapt? }\end{array}$ & 88 & 75 \\
$\begin{array}{l}\text { 3. Various types of products, the structure of various varieties, } \\
\text { high and low proportion is reasonable? }\end{array}$ & 80 & 85 \\
$\begin{array}{l}\text { 4. Are dishes quality standards unified? } \\
\text { Average value }\end{array}$ & 90 & 80 \\
\hline
\end{tabular}

Table 4 Analysis results of food price

\begin{tabular}{|c|c|c|c|c|}
\hline Food and beverage price analysis & $\begin{array}{l}\text { Expected } \\
\text { quality }\end{array}$ & service & $\begin{array}{l}\text { Perceived } \\
\text { quality }\end{array}$ & service \\
\hline 1.Dose the price of dishes and service match? & 90 & & 85 & \\
\hline $\begin{array}{l}\text { 2. Can the prices of dishes and drinks be accepted by } \\
\text { customers? }\end{array}$ & 87 & & 80 & \\
\hline 3. Whether the prices of dishes and drinks match the grade? & 85 & & 80 & \\
\hline 4. Are dishes, drinks prices uniform standards? & 90 & & 80 & \\
\hline Average value & 88 & & 81.25 & \\
\hline
\end{tabular}

Table 5 Analysis results of safety and hygiene

\begin{tabular}{|c|c|c|c|}
\hline Analysis of safety and hygiene & $\begin{array}{l}\text { Expected } \\
\text { quality }\end{array}$ & service & $\begin{array}{l}\text { Perceived service } \\
\text { quality }\end{array}$ \\
\hline Safety and health analysis & 85 & & 75 \\
\hline $\begin{array}{l}\text { 1. Is the sanitary standard of the kitchen operation standard } \\
\text { uniform and up to standard?. }\end{array}$ & 83 & & 70 \\
\hline $\begin{array}{l}\text { 2. Is the hygienic standard of the restaurant and the whole dining } \\
\text { environment standard?. }\end{array}$ & 81 & & 65 \\
\hline $\begin{array}{l}\text { 3. Is the personal hygiene standard of the catering attendant up to } \\
\text { standard?. }\end{array}$ & 76 & & 65 \\
\hline $\begin{array}{l}\text { 4. Whether food and beverage environment, to reassure } \\
\text { customers, safe?. }\end{array}$ & 81.25 & & 68.75 \\
\hline
\end{tabular}


Table 6 Analysis results of service level

\begin{tabular}{|c|c|c|}
\hline Analysis of service level & $\begin{array}{l}\text { Expected service } \\
\text { quality }\end{array}$ & $\begin{array}{l}\text { Perceived service } \\
\text { quality }\end{array}$ \\
\hline $\begin{array}{l}\text { 1. Service dress uniform standard, whether standard, easy and } \\
\text { neat }\end{array}$ & 85 & 75 \\
\hline 2. Service personnel service efficiency is high & 80 & 66 \\
\hline 3. The service of service personnel should be trusted & 88 & 74 \\
\hline 4. Enthusiastic questions from service staff & 80 & 70 \\
\hline 5. Feel comfortable with the service staff & 80 & 65 \\
\hline Average value & 82.6 & 70 \\
\hline
\end{tabular}

Analysis of Resutls. By comparing the expected quality and perceived quality of the rural tourism service, it is concluded that there are many problems in the quality of service at this stage, and the quality of service needs to be improved.

Table 7 Gap table of service quality evaluation

\begin{tabular}{|c|c|c|c|}
\hline $\begin{array}{l}\text { Index of service quality } \\
\text { evaluation }\end{array}$ & Expected service quality & Perceived service quality & Gap value \\
\hline $\begin{array}{l}\text { Hardware, equipment, } \\
\text { atmosphere }\end{array}$ & 82.4 & 73 & 9.4 \\
\hline Dishes quality & 87 & 80 & 7 \\
\hline Catering price & 88 & 81.25 & 6.75 \\
\hline Safety hygiene & 81.25 & 68.75 & 12.5 \\
\hline service level & 82.6 & 70 & 12.6 \\
\hline Characteristic service & 81 & 66.25 & 14.75 \\
\hline
\end{tabular}

\section{Conclusion}

Through the use of rural tourism service quality evaluation model to measure rural tourism makes the service quality and comprehensive service ability. In the evaluation process, the customer of the rural tourism food price and quality as well as the hardware equipment and atmosphere of the three aspects of the identity of the gap is not too large, but in safety and hygiene, service level, especially the characteristics of rural tourism services, flowers still remain in the level of the lower stage, especially in the personalized service, employee performance is not satisfactory. Therefore, standard practice for rural tourism, each need to establish a catering service to staff training, to monitor the quality of service, and should be good at using the service attributes to enhance the quality of service, at the same time, strengthen professional skills and service awareness training, and constantly improve the service quality of the enterprise, improve the comprehensive evaluation of the customer the level and quality of service by surrounding the enhanced the market competitiveness of enterprises. 


\section{References}

[1] Rosa María Yagüe Perales.Rural Tourism in Spain [J]. Annals of Tourism Research, 2002, 29(4): 1101-1110.

[2] Monica Iorio , Andrea Corsale . Rural Tourism and Livelihood Strategies in Romania [J]. Journal of Rural Studies,2009: 1-11.

[3] Cai Xuejie, Lu Linhong. Study on the Strategies of Improving Rural Tourism Service Quality Based on Tourist Satisfaction [J]. Journal of Changsha University, 2014, 28(6): 25-27.

[4] Xu Qi. Rural Tourism Service Quality, Tourist Satisfaction and Tourist Loyalty [J]. Journal of Harbin University of Commerce, 2013(4): 113-119. 